\title{
In silico characterization of molecular factors involved in metabolism and pathogenicity of Phytophthora cinnamomi
}

\author{
Mohamed Belhassan Boughanmi ${ }^{1}$. Iuliia Branco ${ }^{1}$ - Altino Choupina ${ }^{1}$ (i)
}

Received: 24 October 2020 / Accepted: 29 October 2021

(c) The Author(s), under exclusive licence to Springer Nature B.V. 2021

\begin{abstract}
Phytophthora cinnamomi is classified as one of the most devastating plant pathogens in the world. It has a destructive effect on more than 5000 horticultural and forestry species in the world, and especially on Castanea sativa. The genus Phytophthora belongs to the Class Oomycetes, a group of fungus like organisms which provoke plant diseases via motile zoospores. Control of this organism is considered very challenging because of the limited range of effective chemical inhibitors. The development of sustainable control measures for the future management of $P$. cinnamomi requires in-depth knowledge of the cellular and molecular bases of development and metabolism. The aim of this review was to identify molecular factors associated with the metabolism of $P$. cinnamomi by studying the genes implicated in fundamental metabolism using tools of bioinformatics. Also, some genes involved in pathogenicity will be cited and characterized, such as genes coding for transglycosylases. Genomic sequences of P. cinnamomi were analyzed using an open reading frame (ORF) finder. The identified ORFs products (proteins) were compared to sequences already described and with known functions present in databases such as NCBI and fungi database. In this way, homologous proteins were found, with the respective specific domains, to proteins involved in the metabolism and pathogenicity of Phytophthora ssp.
\end{abstract}

Keywords Phytophthora cinnamomi $\cdot$ Oomycetes $\cdot$ Zoospores $\cdot$ Castanea sativa $\cdot$ Open reading frame

\section{Introduction}

Castanea Sativa, known commonly as the chestnut tree, was originally located on the sprinkled reliefs of the north of the Mediterranean, in particular south of the Balkans (especially in Greece), in Italy, in Corsica, in the south-east of France, but also in the Iberian Peninsula (Trás-os-montes region in Portugal and northern Spain), south of the Black Sea in Turkey, then east into the Caucasus, Georgia, Armenia, and Azerbaijan. Its distribution area has been greatly extended by humans into Southern Europe and especially into Western Europe, north to Scotland, and also locally into North Africa [1].

It occupies almost 2 million hectares with a very significant economic contribution in European agriculture [1]. Since the twentieth century, the production of chestnuts has

Altino Choupina

albracho@ipb.pt

1 Centro de Investigação de Montanha (CIMO), Instituto Politécnico de Bragança, Campus de Santa Apolónia, 5300-253 Bragança, Portugal decreased considerably, with losses of around 300 million euros, and chestnuts continue to be seriously threatened by pests such as the disparate woodworm that attacks the wood, and by the codling moth which damages the fruit. However, the real threat comes from pseudo-fungi belonging to the genus Phytophthora. P. cinnamomi (the most virulent species) and $P$. cambivora, both causing ink disease, in addition to the fungus Cryphonectria parasitica, responsible for chestnut cancer [2, 3].

Ink disease is one of the biggest threats to $C$. sativa affecting both the development and economic yield of this important culture. It causes root and collar rot of both adult trees and of seedlings in plantations, nurseries, and forests. In addition, symptoms of the disease include chlorotic leaves which are reduced in size, immature husks remaining on the tree after the leaves have fallen, and thinning of the crown [4].

Moreover, flame shaped dark necrosis is evident on the collar of the tree after debarking. During the spring and the period corresponding to leaves falling, large roots are mainly infected, they start producing a black exudate that stains the surrounding soil. On young trees with 
smooth bark, the necrosis is visible without debarking as depressed, slightly cracked areas at the base of the stem. There is extensive necrosis of the taproot that extends until the lateral roots and up the stem for some centimeters, causing stem cankers [4].

Symptoms of ink disease in the European chestnut $(C$. sativa Miller) were first observed in Spain in 1726. In 1859, the symptoms of the disease were found in the chestnuts in many European countries, including northern Italy and France, as well as in the United States [5, 6]. In Portugal, the first symptoms of ink disease were described in 1838 and more precisely on the banks of the Lima River [7].

This is the taxonomy of Phytophthora cinnamomi Rands; Kingdom Chromista; Phylum Oomycota or Pseudofungi; Class Oomycetes; Order Peronosporales; Family Peronosporaceae; genus Phytophthora [8]. Since the identification of $P$. cinnamomi, it was believed to belong to the fungi kingdom due to similarities with "real fungi" in terms of growth allowed by the polarization of the hyphae, vegetative spores adapted to dispersion by wind or water, and infection strategies employed. Unlike true fungi, this soil-borne pathogen passes most of its life cycle as a diploid, the cell walls are composed of cellulose and $\beta$-glucans instead of chitin, it produces biflagellated zoospores and it does not synthesize sterols, they are resistant to poly- genic antibiotics, such as pimaricin, but requires sterols to sporulate [9].

One of the major characteristics of Chromista is the production of motile asexual spores possessing a flagellum adorned by tubular hairs that are responsible for forward movement $[10,11]$. For many species of Phytophthora, the motile zoospores are the main infective agent initiating plant disease. Phytophthora cinnamomi has been ranked in the top 10 Oomycete plant pathogens due to their scientific importance and economic impact [12]. In California, it has been estimated that losses in avocado crops caused by $P$. cinnamomi exceed US\$40 million annually [13].

Phytophthora cinnamomi is a soil-borne pathogen with sexual and asexual phases in its lifecycle [14]. It can grow on dead organic matter in the saprophytic phase or directly on susceptible hosts during the parasitic phase. Characteristically, $P$. cinnamomi infects fine, feeder roots, but it can also invade woody stems, especially by exploiting wounds or natural breaks in the peridermal layer [15].

The pathogen's growth within the root system causes root necrosis, which influences negatively water uptake and the transport of essential nutrients to the plant, causing wilting and chlorosis of the foliage. Infected plants can remain asymptomatic for many years, or they can die quickly. The ability of $P$. cinnamomi to grow saprophytically in the soil or symptomlessly in infected plants is a major contributing factor to the long-term survival of the pathogen. It is believed that sexual chlamydospores, sexual oospores, and intracellular hyphal aggregates permit the pathogen to survive for long periods under unfavorable conditions and therefore make disease management extremely difficult [16].

Although we know very well the economic, ecological and environmental problems caused by oomycete $P$. cinnam$o m i$ and their mechanisms of infection, increased in recent years by climate change, there is still a lack of knowledge about the metabolism specific and pathogenicity factors of this oomycete.

Some works developed allowed us to characterize some factors (genes and proteins) as necrosis-inducing protein, lyases, transglutaminases, glucanases associated with pathogenicity, however, the metabolism factors specific to this oomycete are little known [3, 8, 17-21]. However, in oomycetes such as Phytophthora infestans these factors have been studied and deepened for a long time [12]. With the genomic sequences deposited in the biological databases (NCBI, EMBL, DDJB, and FungiDB) and using the extraordinary capabilities of modern bioinformatic tools, starting from homology criteria with factors known in oomycetes models like $P$. infestans, we could advance further in the characterization the pathogenicity factors of $P$. cinnamomi and deduce some specific factors of the metabolism of this phytopathogen. These are the factors that allow us to understand how the organism grows, multiplies, and responds to the changing environment.

\section{Methodologies}

\section{Sequence editing and comparison}

For the detailed editing of the sequences was used the BioEdit program, whose version is available at http://www. mbio.ncsu.edu/bioedit/page2.html. We used the Sequencher program from Gene Codes Corporation for sequence comparison and annealing, whose demo copy of version 5.2.4 is available at www.genecodes.com.

\section{Biological information databases}

For the research of genes, we used the sequences of the genome and the transcriptome of $P$. cinnamomi, deposited in the databases:

NCBI (National Center for Biotechnology Information) at https://www.ncbi.nlm.nih.gov/;

EMBL (European Molecular Biology Laboratory) at www.ebi.ac.uk/ena

DDJB (DNA Data Bank of Japan) at www.ddbj.nig.ac.jp/

FungiDB (The Fungal and Oomycete Genomics Resource) at fungidb.org.

The genomic sequence used in this work is deposited in NCBI under the reference: P. cinnamomi isolate MP94$48(5,831$ rc linear DNA). 


\section{Open reading frame search}

For the search of open reading frames, in the sequences of the genome and the transcriptome of P. cinnamomi, the following programs were used:

- ORF finder NCBI at https://www.ncbi.nlm.nih.gov/orffi nder/;

- GGENEinfinity at http://www.geneinfinity.org/sms/ sms_orffinder.html;

- GGenScript at https://www.genscript.com/sms2/orf_ find.html.

\section{Gene predictions}

For gene prediction from the Contig 1 sequence of $P$. cinnamomi isolate MP94-48 assembly, we use the Maker program. MAKER identifies repeats, aligns ESTs and proteins to a genome, produces ab initio gene predictions, and automatically synthesizes these data into gene annotations having evidence-based quality indices [22].

\section{Homology of proteins encoded by open reading frames}

Detection of protein homology and sequence alignment underlies the prediction of protein structure, function, and evolution. Protein homologies were determined in the Blast (smartBlast), Clustal Omega, and Fasta programs independently or through NCBI (National Center for Biotechnology Information). Homology is established with the Protein Databases sequences: UniProt Universal Resource (EBI), Protein Information Resource [PIR, Georgetown University Medical Center (GUMC)], Swiss-Prot Protein Knowledgebase (Swiss Institute of Bioinformatics), and PROSITE (Database of Protein Famines and Domains).

\section{Subcellular location of identified proteins of $P$. cinnamomi}

The prediction of the subcellular location of proteins predicts the fate of a protein in the cell, using computational methods with the protein sequence.

There are several publicly available softwares, using different methods to predict protein localization (amino acid composition, signal peptide composition, physicochemical composition, among others), which is a very important part of the prediction based on protein function bioinformatics and genome annotation.

The packages used for the prediction of protein localization were accessed at the following URL:

SignalP 3.0: http://www.cbs.dtu.dk/services/SignalP-3.0/; Cello: http://cello.life.nctu.edu.tw/;

LOCtree: https://rostlab.org/services/loctree2/;
EuK-mPLoc 2.0: http://www.csbio.sjtu.edu.cn/bioinf/ euk-multi-2/;

Esl pred: http://www.imtech.res.in/raghava/eslpred/index. html

\section{Bioinformatics characterization of molecular factors}

After decoding the open reading frame of a gene, a number of bioinformatics tools can be used to characterize the deduced sequence of the protein. A search on the Expasy Proteomics Server website (http://expasy.org/tools) and a nucleotide sequence allows us to identify and characterize proteins, identify motifs, patterns, and profiles, infer their stability, cell location or function, predictions of secondary and tertiary structures, look for similar sequences deposited in databases and compare them, and establish phylogenetic relationships.

The detection of the physical-chemical characteristics of the proteins was carried out in PROSITE (http://prosite. expasy.org/scanprosite/), in the neural network system of the Pôle BioInformatique Lionnais/Network Protein Sequence Analysis or in the application DiANNA 1.1 (http://clavius. bc.edu/ clotelab/DiANNA/). Different sites were predicted for post-translational modifications on the Center of Biological Sequence Analysis website (http://www.cbs.dtu.dk/ services).

\section{Gene prediction from the Contig 1 sequence of $P$. cinnamomi isolate MP94-48}

We used the Maker program, as it is a robust analysis program, to gene prediction from the Contig 1 sequence of $P$. cinnamomi isolate MP94-48, in order to obtain broader functional genomics analysis and prediction of metabolic pathways. Table 1 shows the results of this analysis with the NCBI reference number of the homologous gene, the organism, the designation of the protein product, and the region of the contig where the sequence is found. Genes with the most significant homology (greater than $85 \%$ ) and with participation in significant aspects of cellular metabolism were selected for the table. As we can see, these genes have homology with genes from species of the genus Phytophthora as expected by the phylogenetic proximity.

As expected, these genes encode products that participate in different aspects of the cellular metabolism of $P$. cinnamomi, from enzymes that participate in the synthesis of Aminoacyl-tRNA synthetases, essential in protein synthesis, genes that encode products of biosynthesis and metabolism of various biomolecules such as glycolipids, to genes that encode products with a significant role in cell phase changes and in the synthesis of environmental adaptation and genes that encode pathogenicity products [23-26]. 
Table 1 Molecular factors of Phytophthora cinnamomi metabolism, deduced with the Maker tool from contig 1 of strain MP94-48

\begin{tabular}{|c|c|c|c|}
\hline NCBI ref & Contig region & Product definition & Species \\
\hline POM73604.2 & NCKW01005070.1:1..7903 (+strand) & GPI ethanolamine phosphate transferase & Phytophthora palmivora var. palmivora \\
\hline KAF1795552.1 & $\begin{array}{l}\text { NCKW01005070.1:5353..13255 } \\
\quad(+ \text { strand })\end{array}$ & Rof/RNase P-like & Phytophthora cactorum \\
\hline POM70932.1 & $\begin{array}{l}\text { NCKW01005070.1:5662..13564 } \\
\text { (+ strand) }\end{array}$ & Pleckstrin-like protein & Phytophthora palmivora var. palmivora \\
\hline KAF1795547.1 & $\begin{array}{l}\text { NCKW01005070.1:5662..13564 } \\
\text { (+ strand) }\end{array}$ & $\begin{array}{l}\text { Serine-tRNA synthetase, type } 1, \\
\text { N-terminal }\end{array}$ & Phytophthora cactorum \\
\hline OWZ24232.1 & $\begin{array}{l}\text { NCKW01005070.1:5662..13564 } \\
(+ \text { strand })\end{array}$ & COP9 signalosome complex subunit & Phytophthora megakarya \\
\hline POM71256.1 & $\begin{array}{l}\text { LNFO01000046.1:33571...47822 } \\
\text { (+ strand })\end{array}$ & Pol protein & Phytophthora palmivora var. palmivora \\
\hline KAE8878987.1 & $\begin{array}{l}\text { LNFO01000046.1:33571...47822 } \\
\text { (+ strand) }\end{array}$ & Transposon Tf2-6 polyprotein & Phytophthora fragariae \\
\hline KAF1795549.1 & $\begin{array}{l}\text { LNFO01000046.1:33571...47822 } \\
\text { (+ strand) }\end{array}$ & Sterile alpha motif/pointed domain & Phytophthora cactorum \\
\hline ABG66531.1 & $\begin{array}{l}\text { LNFO01000046.1:32716..46967 } \\
\text { (+ strand) }\end{array}$ & Reverse transcriptase, partial & Phytophthora sojae \\
\hline OWZ00916.1 & $\begin{array}{l}\text { LNFO01000046.1:32716..46967 } \\
\text { (+ strand })\end{array}$ & Pol Polyprotein & Phytophthora megakarya \\
\hline OWZ00482.1 & $\begin{array}{l}\text { LNFO01000046.1:33005..47256 } \\
\text { (+ strand })\end{array}$ & Polyprotein & Phytophthora megakarya \\
\hline KAE9028524.1 & LNFO01000046.1:1..14252 & Callose synthase 1 & Phytophthora fragariae \\
\hline KAF1795554.1 & LNFO01000046.1:1..14252 & $\begin{array}{l}\text { 1,3-beta-glucan synthase subunit FKS1- } \\
\text { like, domain-1 }\end{array}$ & Phytophthora cactorum \\
\hline KAE9233925.1 & LNFO01000046.1:1..14252 & Callose synthase 9 & Phytophthora fragariae \\
\hline OWZ24222.1 & $\begin{array}{l}\text { LNFO01000046.1:14399..28650 } \\
\quad(+ \text { strand })\end{array}$ & Endoplasmic oxidoreductin & Phytophthora megakarya \\
\hline KAF1795547.1 & $\begin{array}{l}\text { LNFO01000046.1:14399..28650 } \\
\text { (+ strand) }\end{array}$ & $\begin{array}{l}\text { Serine-tRNA synthetase, type1, } \\
\text { N-terminal }\end{array}$ & Phytophthora cactorum \\
\hline OWZ24233.1 & $\begin{array}{l}\text { LNFO01000046.1:14399..28650 } \\
\text { (+ strand })\end{array}$ & Seryl-tRNA synthetase & Phytophthora megakarya \\
\hline KAE8911029.1 & $\begin{array}{l}\text { LNFO01000046.1:14399..28650 } \\
\text { (+ strand) }\end{array}$ & Serine-tRNA ligase, cytoplasmic & Phytophthora fragariae \\
\hline OWZ24236.1 & $\begin{array}{l}\text { LNFO01000046.1:14399..28650 } \\
\quad(+ \text { strand })\end{array}$ & Carbohydrate esterase & Phytophthora megakarya \\
\hline KAF1795539.1 & $\begin{array}{l}\text { LNFO01000046.1:14399..28650 } \\
\quad(+ \text { strand })\end{array}$ & NAD(P)-binding domain & Phytophthora cactorum \\
\hline KAF1795555.1 & $\begin{array}{l}\text { LNFO01000046.1:14399..28650 } \\
\quad(+ \text { strand })\end{array}$ & Class I glutamine amidotransferase-like & Phytophthora cactorum \\
\hline KAF1795557.1 & $\begin{array}{l}\text { LNFO01000046.1:14399..28650 } \\
\text { (+ strand) }\end{array}$ & $\begin{array}{l}\text { Aldehyde dehydrogenase, glutamic acid } \\
\text { active site }\end{array}$ & Phytophthora cactorum \\
\hline POM71642.1 & $\begin{array}{l}\text { LNFO01000046.1:14399..28650 } \\
\text { (+ strand) }\end{array}$ & Cysteine protease family C26 & Phytophthora palmivora var. palmivora \\
\hline POM71643.1 & CKW01006442.1:5255..17840 (+ strand) & Endoplasmic oxidoreductin & Phytophthora palmivora var. palmivora \\
\hline KAE9012269.1 & NBNE01003014.1:1..7752 & $\begin{array}{l}\text { Eukaryotic translation initiation factor } 3 \\
\text { subunit C }\end{array}$ & Phytophthora rubi \\
\hline KAE9305923.1 & NBNE01003014.1:1..7753 & $\begin{array}{l}\text { Eukaryotic translation initiation factor } 3 \\
\text { subunit C }\end{array}$ & Phytophthora fragariae \\
\hline POM80617.1 & NBNE01003014.1:1..7754 & $\begin{array}{l}\text { Eukaryotic translation initiation factor } 3 \\
\text { subunit C }\end{array}$ & Phytophthora palmivora var. palmivora \\
\hline POM59598.1 & NBNE01003014.1:1..7755 & $\begin{array}{l}\text { MFS transporter, LAT3 family, solute } \\
\text { carrier family } 43 \text {, member } 3\end{array}$ & Phytophthora palmivora var. palmivora \\
\hline OWZ08811.1 & NBNE01003014.1:1..7756 & Aspartyl protease & Phytophthora megakarya \\
\hline KAF1794292.1 & NBNE01003014.1:1..7757 & DNA/RNA-binding protein Alba-like & Phytophthora cactorum \\
\hline
\end{tabular}




\section{Molecular factors}

In this work, we used the genomic sequence deposited in NCBI under the following reference: $P$. cinnamomi isolate MP94-48(5,831 rc linear DNA). Firstly, Contigs from this assembly were analysed via the ORF finder tool in order to find out the ORFs from these random sequences (contigs). Secondly, we performed a smart blast with the identified ORFs to find homologs of molecular factors already described in other pseudo-fungi, such as Phytophthora sojae, $P$. infestans, with known pathways and functions. These molecular factors are the divided into two classes: implicated in fundamental metabolism and others involved in pathogenicity (Tables 2 and 3). This classification was based on bibliography, conserved domains, and subcellular location of molecular factors of interest using SignalP and Cello tools. Furthermore, the subcellular location of the proteins may be carried out in another way through the design of cassettes containing GFP sequences, followed by fluorescence microscopy, which is more precise, but also more time and money consuming. Proteins which have extracellular locations are considered to be involved in pathogenicity, those which do not have extracellular locations (nuclear, cytoplasmic, and mitochondrial) are considered to be involved in fundamental metabolism. This classification was in agreement with what has been shown in the literature.

In Tables 2 and 3, each cited protein is codified by a specific ORF, which was identified as described in the previous part with its contig number and the name of the homolog organism. Proteins are described in terms of function and subcellular location as mentioned above. Each protein is defined by its NCBI gene bank accession.

Despite the large amount of research and analysis carried out on the Phytophthora genome, until now there is not sufficient information to carry out a treatment to eradicate or at least mitigate the impact of ink disease. In previous reviews, the major focus was given to genes directly implicated in pathogenicity, such as the NPP1 gene, which has been shown to trigger root necrosis in host cells. The GIP gene responsible for the suppression of the host defense response. The GLUCANASES gene family responsible for adhesion, penetration, and colonization in host tissues have also been well studied [17, 27] (see Table 4).

We made a comparison of the proteins deduced from the obtained open reading phases, in order to find homologous proteins characterized in other living organisms and deposited in the Uniprot and Swiss-Prot protein databases. In both sources, most of the open reading phases encode proteins homologous to metabolic and pathogenic proteins

Table 2 Phytophthora cinnamomi, molecular factors involved in fundamental metabolism

\begin{tabular}{|c|c|c|c|c|c|c|}
\hline Contig & Protein length & Homolog organism & Name of protein & Localization & Function & Accession \\
\hline \multirow[t]{3}{*}{1} & $137 \mathrm{aa}$ & $\begin{array}{l}\text { Phytophthora mega- } \\
\quad \text { karya }\end{array}$ & Polycomb protein & Nuclear & $\begin{array}{l}\text { Direct } \\
\text { Assembly of transcrip- } \\
\text { tionaly repressed } \\
\text { chromatin [50] }\end{array}$ & GenBank: OWZ24764.1 \\
\hline & $132 \mathrm{aa}$ & $\begin{array}{l}\text { Phytophthora cacto- } \\
\text { rum }\end{array}$ & & & & $\begin{array}{l}\text { GenBank: } \\
\text { KAF1784310.1 }\end{array}$ \\
\hline & 113 aa & $\begin{array}{l}\text { Phytophthora cacto- } \\
\text { rum }\end{array}$ & $\begin{array}{l}\text { Nucleotide-binding } \\
\text { alpha-beta plait } \\
\text { domain }\end{array}$ & Nuclear & RNA binding [51] & $\begin{array}{l}\text { GenBank: } \\
\text { KAF1773404.1 }\end{array}$ \\
\hline \multirow[t]{3}{*}{2} & $166 a a$ & $\begin{array}{l}\text { Phytophthora mega- } \\
\quad \text { karya }\end{array}$ & $\begin{array}{l}\text { P21-activated protein } \\
\text { kinase-interacting } \\
\text { protein }\end{array}$ & $\begin{array}{l}\text { Nuclear and } \\
\text { mainly cytoplas- } \\
\text { mic }\end{array}$ & $\begin{array}{l}\text { Regulate cell shape } \\
\text { and polarity [52] }\end{array}$ & GenBank: OWZ18359.1 \\
\hline & 121 aa & $\begin{array}{l}\text { Phytophthora mega- } \\
\text { karya }\end{array}$ & $\begin{array}{l}\text { Glucose repression } \\
\text { regulatory protein } \\
\text { TUP1 }\end{array}$ & Nuclear & $\begin{array}{l}\text { Greatly implicated in } \\
\text { glucose repression } \\
\text { and affect mating } \\
\text { type [28] }\end{array}$ & GenBank: OWZ07049.1 \\
\hline & 241 aa & $\begin{array}{l}\text { Phytophthora cacto- } \\
\text { rum }\end{array}$ & Frag1/DRAM/Sfk1 & Plasma membrane & $\begin{array}{l}\text { Induces macro- } \\
\text { autophagy as an } \\
\text { effector of p53-medi- } \\
\text { ated death [53] }\end{array}$ & $\begin{array}{l}\text { GenBank: } \\
\text { KAF1793710.1 }\end{array}$ \\
\hline 3 & 177 aa & Phytophthora infestans & Rap1 Myb domain & & $\begin{array}{l}\text { critical for maintain- } \\
\text { ing normal telomere } \\
\text { length and structure } \\
\text { [54] }\end{array}$ & $\begin{array}{l}\text { GenBank: } \\
\text { KAF4146400.1 }\end{array}$ \\
\hline 102 & 791 aa & $\begin{array}{l}\text { Phytophthora mega- } \\
\quad \text { karya }\end{array}$ & Clavaminate synthase & Cytoplasmic & $\begin{array}{l}\text { conversion of pro- } \\
\text { clavaminic acid to } \\
\text { clavaminic acid [40] }\end{array}$ & GenBank: OWZ22087.1 \\
\hline
\end{tabular}


Table 3 Phytophthora cinnamomi, molecular factors involved in pathogenicity

\begin{tabular}{|c|c|c|c|c|c|c|}
\hline Contig & ORF's length & Homolog organism & Name of protein & Localization & Function & Accession \\
\hline \multirow[t]{2}{*}{102} & 406 & $\begin{array}{l}\text { Phytophthora mega- } \\
\quad \text { karya }\end{array}$ & Murein transglycosylase & Extracellular & $\begin{array}{l}\text { Involved in the biogen- } \\
\text { esis of the cell wall, } \\
\text { required for growth, } \\
\text { invading ecological } \\
\text { niches, and counteract- } \\
\text { ing the host immune } \\
\text { response [40] }\end{array}$ & GenBank: OWZ01054.1 \\
\hline & $135 \mathrm{aa}$ & Phytophthora sojae & Elicitin & Extracellular & $\begin{array}{l}\text { Elicitin proteins produce } \\
\text { metabolic or structural } \\
\text { changes in host cells } \\
\text { that aid pathogen } \\
\text { growth and favour the } \\
\text { development of the } \\
\text { disease [8] }\end{array}$ & $\begin{array}{l}\text { GenBank: } \\
\quad \text { XP_009524940.1 }\end{array}$ \\
\hline \multirow[t]{3}{*}{81} & & Phytophthora ramorum & $\begin{array}{l}\text { Elicitin-like protein } \\
\text { RAL11D }\end{array}$ & Extracellular & & $\begin{array}{l}\text { GenBank: } \\
\text { ABB55948.1 }\end{array}$ \\
\hline & $135 \mathrm{aa}$ & & & & & \\
\hline & 478aa & $\begin{array}{l}\text { Phytophthora mega- } \\
\text { karya }\end{array}$ & $\begin{array}{l}\text { Transglutaminase elici- } \\
\text { tor, partial }\end{array}$ & Extracellular & $\begin{array}{l}\text { Involved in the estab- } \\
\text { lishment of Phytoph- } \\
\text { thora disease during } \\
\text { early phases [8] }\end{array}$ & $\begin{array}{l}\text { GenBank: } \\
\text { OWY99932.1 }\end{array}$ \\
\hline 101 & 478aa & $\begin{array}{l}\text { Phytophthora palmivora } \\
\text { var. palmivora }\end{array}$ & $\begin{array}{l}\text { Transglutaminase } \\
\text { elicitor-like protein }\end{array}$ & Extracellular & & $\begin{array}{l}\text { GenBank: } \\
\text { POM62262.1 }\end{array}$ \\
\hline 95 & $118 \mathrm{aa}$ & $\begin{array}{l}\text { Phytophthora palmivora } \\
\text { var. palmivora }\end{array}$ & $\begin{array}{l}\text { Polysaccharide lyase, } \\
\text { partial }\end{array}$ & Extracellular & $\begin{array}{l}\text { Enzyme involved in } \\
\text { plant polysaccharide } \\
\text { and pectin degrada- } \\
\text { tions [55] }\end{array}$ & GenBank: POM79686.1 \\
\hline 108 & $115 \mathrm{aa}$ & $\begin{array}{l}\text { Phytophthora palmivora } \\
\text { var. palmivora }\end{array}$ & Zinc ion binding protein & Extracellular & $\begin{array}{l}\text { Sequester zinc from host } \\
\text { cells and tissues [56] }\end{array}$ & GenBank: POM72001.1 \\
\hline
\end{tabular}

Table 4 Genes linked to pathogenicity in P. cinnamomi [18]

\begin{tabular}{|c|c|c|c|}
\hline Name of Gene & source & Name of the protein & Function \\
\hline Endo1 & $\begin{array}{l}\text { NCBI } \\
\text { Accession: AM259651 }\end{array}$ & Glucan 1,3-beta-D-glucosidase & $\begin{array}{l}\text { Cell morphogenetic processes, especially in } \\
\text { the infection process }\end{array}$ \\
\hline Gip & $\begin{array}{l}\text { NCBI } \\
\text { Accession: AM259384 }\end{array}$ & Glucanase inhibitor protein & $\begin{array}{l}\text { Responsible for suppressing the host's } \\
\text { defense response }\end{array}$ \\
\hline Npp1 & $\begin{array}{l}\text { NCBI } \\
\text { Accession: AM403130 }\end{array}$ & Protein 1 & $\begin{array}{l}\text { It causes necrosis in the leaves and roots of } \\
\text { the plant }\end{array}$ \\
\hline Transglu & $\begin{array}{l}\text { NCBI } \\
\text { Accession: AM403129 }\end{array}$ & Transglutaminase elicitor precursor & $\begin{array}{l}\text { It induces defense responses and symptoms } \\
\text { similar to that of the disease }\end{array}$ \\
\hline Endoglucanase & {$[60]$} & Endo-1,3-beta-glucanase & Responsible for infection mechanisms \\
\hline Exoglucanase & {$[60]$} & exo-glucanase & $\begin{array}{l}\text { Responsible for adhesion, penetration and } \\
\text { colonization in the host's tissues }\end{array}$ \\
\hline ADP-ribosylation factor & {$[61]$} & ADP-ribosylation factor & Responsible for infection mechanisms \\
\hline Ric1 protein mrna & {$[61]$} & Ric1 protein mRNA & Responsible for infection mechanisms \\
\hline Polygalacturonase 4 1, 2, 3 e 4, 5, 6 & {$[62]$} & Polygalacturonase 4 & $\begin{array}{l}\text { Breakdown in the cell wall composition of } \\
\text { plant cells }\end{array}$ \\
\hline Highly acidic elicitin & [63] & Highly acidic elicitin & Responsible for infection mechanisms \\
\hline
\end{tabular}


of different species of the genus Phytophthora, as expected, especially $P$. infestans, $P$. sojae, Phytophthora nicotinea, and Phytophthora parasitica. There were also a large number of open reading frames that coded for hypothetical proteins and/or with unknown functions.

\section{Characterization of genes involved in metabolism}

A bioinformatic analysis of the Phytophthora genomic sequences allowed us to identify several genes involved in metabolism, the most important of which code for proteins belonging to several families, namely kinases, ligases, polymerases, transferases, and methylases. Metabolism is the set of thousands of chemical reactions of anabolism and catabolism by proteins which are in turn coded for by specific genes. The good functioning of the mechanisms will allow survival and development and consequently enhance the virulent power of the pathogen.

\section{Characterization of TUP 1 gene in P. cinnamomi}

In contig 2 (LGSJ01000002.1 sequence in NCBI), an ORF with a length of 121aa (366nt) has been identified as a homolog of TUP 1 (glucose repression regulatory protein). It has a high percentage of homology equal to $83.19 \%$ with TUP1 of Phytophthora megakarya according to smart blast; also this isolated ORF has a very significant coverage up to 93\% with the same gene of P. megakarya. TUP 1 is a gene involved in the repression of glucose for a multitude of genes and also influences the type of mating, and an induced mutation of this gene has reduced the degree of repression of glucose considerably, changed mating type, and disrupted some other pathways [28]. TUP 1 affecting the reproduction of the species, can be considered as one of the ways to inhibit the pathogen. The analysis of the sequence revealed 2 conserved domains, WD40 (accession: cl29593) and DUF2205 (accession: cl10911).

\section{Characterization of Rap1 gene in P. cinnamomi}

Analysis of the sequence LGSJ01000003.1 from $P$. cinnamomi taken from NCBI, with the ORF research platform, as described in the Methodologies section, revealed an ORF of length equal to 366 nucleotides/121aa, which has a significant coverage and homology of $98 \%$ and 65.28\%, respectively, with Myb Rap 1 domain of $P$. infestans. Rap1 (repressor activator protein 1) was first discovered in budding yeast, Saccharomyces cerevisiae, as a positive transcriptional regulator of multiple growthrelated genes, such as ribosomal protein genes [29]. Other studies have identified Rap1 as the main repeat binding protein for double-stranded telomeres in S. cerevisiae and necessary for maintaining the length and structural integrity of telomeres [30, 31]. Indeed, telomeres are specialized nucleoprotein structures that preserve the integrity of eukaryotic chromosomal terminations by protecting them from fusion and recombination and by initiating their replication (for reviews, see references 32-34). In most organisms, telomeric DNA is made up of short repetitive sequences characterized by an abundant presence of $\mathrm{G}$ residues on the strand containing the 3 'end. These repeat sequences are maintained by a ribonucleoprotein (RNP) known as telomerase, acting as an unusual reverse transcriptase $[35,36]$. Telomeric binding proteins and telomerase are both essential for preserving the integrity of telomeres through multiple cell divisions, which in turn are essential for supporting genome stability and extend the lifespan of cell. The Myb domain binding to the DNA of $C$. albicans Rap1 is sufficient to suppress most of the aberrations of the telomeres observed in the null mutant. In addition, in a recent analysis, Rap1 was recognized as a key component of the coupling-type silencer and has been shown to be essential for transcriptional silence [37-39].

\section{Characterization of gene coding for clavaminate synthase in $P$. cinnamomi}

Clavaminate synthase is an enzyme involved in metabolism. The gene coding for this protein has been identified in the following reference sequence LGSJ01000102.1 of the genome of $P$. cinnamomi deposited in the NCBI platform using the ORF finder tool. The identified ORF has a length of 2376 nucleotides which corresponded to 792 amino acids.

This fragment has a very significant percentage of query cover and homology with the pseudo fungus of the same genus, P. megakarya, having percentages of $100 \%$ and $79.90 \%$, respectively. It is an enzyme that has industrial utility and more specifically in the pharmaceutical field. It catalyzes the reaction of the transformation of proclavaminic acid into clavaminic acid [40]. This molecule has proven synergistic effects when combined with beta-lactam antibiotics, such as amoxicillin. This combination is used only in patients suspected of infections with beta-lactamase-producing bacteria.

Amoxicillin is a beta-lactam antibiotic that disrupts the synthesis of the bacterial cell wall by binding to penicillin-binding proteins present inside the bacterial cell wall, thereby preventing the synthesis of the peptidoglycan layer in the cell membrane [41]. This disruption of cell wall synthesis results in cell lysis and bacterial death. In some cases, the bacterial species produce the beta-lactamase enzyme, which can inactivate beta-lactam drugs by hydrolyzing the beta-lactam bond in the antibiotic compound, leading 
to drug resistance. In this case, clavulanic acid at its betalactam bond binds to the active site of beta-lactamase and inactivates the enzyme, thereby improving the antibacterial effect of beta-lactam antibiotics.

\section{Characterization of genes involved in mechanisms of pathogenicity of $P$. cinnamomi}

In this section, we will shed light on the molecular factors thought to directly trigger an infection in a host cell. Thus, all the genes cited code for extracellular proteins according to the bioinformatic tools described in the methodologies. The function of each protein will be discussed by referring to the function of its counterpart already described in other living organisms.

\section{Characterization of murein tranglycosylase gene in $P$. cinnamomi}

Analysis of the sequence LGSJ01000102.1 from P. cinnamomi available in the NCBI, with the ORF finder tool revealed an ORF of length equal to 1221 nucleotides/406aa, which has a significant coverage and homology equal to $99 \%$ and $83.74 \%$, respectively, with a gene coding for murein transglutaminase from P. megakarya.

The fungal cell wall is an essential structure that maintains cell form and protects fungi against environmental critical conditions. Glycosyltransferases, glycoside hydrolases, and transglycosylases are involved in the biogenesis of the cell wall, responsible for growth, invading ecological niches, and counteracting the host immune response. Murein transglycosylase is a lytic enzyme that belongs to the class of autolysin that cleaves the cell wall heteropolymer peptidoglycan (murein) to facilitate its biosynthesis and regeneration [42]. Moreover, the protein function described is in agreement with the extracellular localization deduced, since this enzyme is involved in the maintenance of cell structure and growth. In Aspergillus fumigatus, a family of five $\mathrm{Crh}$ transglycosylases was detected. Indeed, in vitro biochemical assays and localization studies demonstrated that detected enzymes are specifically transglycosylases for both chitinglucan and chitin-chitin cell wall linkages forming a threedimensional network mesh required to strengthen cell wall and ensure its integrity. Furthermore, crh genes aren't only dispensable for cell viability when ensuring cellular turnover but also renders cells sensitive to cell wall interfering compounds [43]. This makes this gene a target to be taken into consideration in order to inhibit or disrupt pathogen growth.

It was found that in the fungus Botrytis cinerea the protein $\mathrm{Crh}(\mathrm{BcCrh})$ is a cytoplasmic effector that is internalized in the plant cell for the induction of cell death and consequently with a great function in the pathogenicity of the fungus. During saprophytic growth, the $\mathrm{BcCrh} 1$ protein is localized in vacuoles and ER. Upon plant infection the protein accumulates to high levels in infection cushions, it is then secreted to the apoplast and translocated into plant cells, where it induces cell death and defense responses, as was well explained by the authors of the reference [44].

\section{Characterization of polysaccharide lyase gene in $P$. cinnamomi}

Polysaccharide lyase is an enzyme involved in plant polysaccharide and pectin degradation. The gene coding for this protein has been identified in the following reference sequence LGSJ01000095.1 of the genome of P.cinnamomi deposited in the NCBI platform using the ORF finder tool, and the identified ORF has a length of 357 nucleotides, which correspond to 118 amino acids.

This fragment has a very significant percentage of query cover and homology with the pseudo fungus of the same genus $P$. palmivora var. palmivora, having percentages of $100 \%$ and $91.53 \%$, respectively. Fungal enzymes involved in plant polysaccharide degradation are assigned to at least 35 glycoside hydrolase (GH) families, three carbohydrate esterase (CE) families, and six polysaccharide lyase (PL) families $[45,46]$. Thereby, the identified query coding for polysaccharide lyase has the power to degrade pectin backbones when combined with glycoside hydrolases [46, 47]. In addition to that, the analysis of this protein has shown the conservation of specific domain pectate lyase (accession: pfam03211) responsible for pectin degradation belonging to the pectate lyase superfamily according to sequence analysis of conserved domains carried out with NCBI [19-21].

\section{Characterization of the gene coding for the zinc ion binding protein in P. cinnamomi}

Analysis of the sequence LGSJ01000108.1 from $P$. cinnamomi available in the NCBI, with the ORF finder tool, revealed an ORF of length equal to 348 nucleotides/115aa, which has a significant coverage and homology respectively equal to $80 \%$ and $55.9 \%$, with a gene coding for a zincophore-like protein from P. palmivora var. palmivora.

Zinc is fundamental for all domains of life, as it composes the catalytic and structural center of a large array of proteins. It is a ubiquitous metal in all life forms, as it is a structural component of almost $10 \%$ of eukaryotic proteins. In fact, zinc-depleting conditions are known to reduce fungal growth and evidence suggests that host cells employ sequestration of zinc to inhibit fungal development [48]. In order to overcome this defence system, pathogenic fungi activate the expression of several systems to enhance the uptake of zinc, through secretion of zincophores, which are proteins able to chelate zinc. 


\section{Characterization of a gene coding for elicitor protein in $P$. cinnamomi}

Analysis of the sequence LGSJ01000081.1 from P. cinnamomi genome available in the NCBI, with the ORF finder tool, revealed an ORF of length equal to 408 nucleotides/135aa, which has significant homology with elicitin proteins from P. sojae and P. rammourm, equal to $75.56 \%$ and $68.22 \%$, respectively.

During infection, P. cinnamomi secretes a diverse range of effector molecules in order to infect the plant. The intended function of these effectors is to facilitate the establishment of disease during the infection. From the plant's point of view, the goal is to recognize the effectors and induce a defense response that will inhibit or mitigate the development of the disease. When an intended effector is recognized by the plant and elicits a defense response, it is termed an avirulence factor or elicitor. Elicitins are classified as apoplastic effectors, meaning that they are secreted into the plant extracellular space. In fact, elicitin proteins produce metabolic or structural changes in host cells that aid pathogen growth and favour the development of the disease [8].

The analysis of conserved domains in this identified homolog with NCBI conserved domain option has revealed the presence of elicitin domain (Accession: pfam00964). This domain occupies a significant part of the protein in terms of length, from position 21 to position 113, and is believed to induce leaf necrosis in infected plants and elicit an incompatible hypersensitive-like reaction.

\section{Characterization of a gene coding for transglutaminase elicitor-like protein in $P$. cinnamomi}

As in other's cases described, analysis of the sequence LGSJ01000101.1 from P. cinnamomi genome available in the NCBI, with the ORF finder tool, revealed an ORF of length equal to 1437 nucleotides/478aa, which has significant homology with transglutaminase elicitin like-protein from P. megakarya and Phytophthora palmivora var. palmivora equal to $59.86 \%$ and $54.61 \%$, respectively.

Transglutaminases are omnipresent in multiple Phytophthora species and catalyze an acyl transfer reaction that provides peptide bonds with more resistance to proteolytic degradation. They are expressed during early infection, suggesting that they may function during the establishment of Phytophthora disease [49].The analysis of conserved domains in this identified homolog with NCBI conserved domain option has revealed the presence of the TGase_elicitor domain (Accession: cl25039). This domain occupies a significant part of the protein in terms of length, from position 147 to position 475, and is believed to trigger infections in the early stages.

\section{Conclusions and future trends}

With the advances in sequencing capacity, with the emergence of the recent large-scale sequencing platforms, it was possible to advance the sequencing of the $P$. cinnamomi genome. However, this structural genomics is just a code whose meaning is necessary to deduce to understand that genes and proteins are involved in the growth, multiplication, and adaptation to the constantly changing environment as well as explaining the great capacity in a number of hosts and aggressiveness of this devastating oomycete. Thus, this work sought to increase the list of these factors (genes and proteins) using modern bioinformatics tools and $P$. cinnamomi sequences deposited in databases. In future research, it is necessary to continue to identify more key molecular factors of metabolism and pathogenicity to understand how it infects plants. The infection of small plants of $C$. sativa or another host with $P$. cinnamomi strains and the consequent sequencing of transcripts with the RNA-seq technique will be an interesting approach that will allow us to determine the main factors in a comprehensive way, as well as the interaction between them in the development of the infection.

Funding The authors are grateful to the Foundation for Science and Technology (FCT, Portugal) and FEDER under Programme PT2020 for financial support to CIMO (UID/AGR/00690/2019).

\section{Declarations}

Conflict of interest The authors declare that they have no conflict of interest.

Ethical approval This article does not contain any studies with human participants or animals performed by any of the authors.

\section{References}

1. Gomes-Laranjo J, Peixoto F, Ferreira-Cardoso J (2009) Castanheiros, Técnicas e Práticas, 1st edn. Pulido Consulting-Industria Criativa \& Universidade de Trás-os- Montes e Alto Douro

2. Silva J (2007) Árvores e florestas de Portugal: do castanheiro ao teixo. As outras espécies florestais, vol 5, Publico, Comunicação Social, S.A, Lisboa

3. Costa R, Bragança H, Machado H (2011) Os últimos 75 anos de investigação para o melhoramento do castanheiro em Portugal. Agrorrural - Contributos Cientíicos, 915-926

4. Vannini A, Vettraino AM (2001) Ink disease in chestnuts: impact on the European chestnut. For Snow Landsc Res 76:345-350

5. Crandall S (1950) The distribution and significance of the chestnut root rot Phytophthoras, $P$. cinnamomi and $P$. cambivora. Plant Dis Rep 34(6):194-196

6. Elorrieta J. El castaño en España. IFIE, Madrid, p 333. Cit. by Gomes-Laranjo J, Peixoto F, Ferreira-Cardoso J (2009); Castanheiros, Técnicas e Práticas. 1st edn. (1949) Pulido Consulting 
- Industria Criativa \& Universidade de Trás-os-Montes e Alto Douro

7. Fernandes C (1953) A luta contra a "doença da tinta" dos castanheiros no Norte de Portugal. Separata das publicações da Direção Geral dos Serviços Florestais e Aquícolas XX:153-158

8. Hardham AR, Blackman LM (2018) Phytophthora cinnamomi. Mol Plant Pathol. https://doi.org/10.1111/mpp.12568

9. Erwin D, Ribeiro O (1996) Phytophthora diseases worldwide. APS Press, St. Paul

10. Beakes GW, Glockling SL, Sekimoto S (2012) The evolutionary phylogeny of the oomycete "fungi." Protoplasma. https://doi.org/ 10.1007/s00709-011-0269-2

11. Cahill DM, Cope M, Hardham AR (1996) Thrust reversal by tubular mastigonemes: immunological evidence for a role of mastigonemes in forward motion of zoospores of Phytophthora cinnamomi. Protoplasma. https://doi.org/10.1007/BF01273164

12. Kamoun S, Furzer O, Jones JDG, Judelson HS, Ali GS, Dalio RJD, Roy SG, Schena L, Zambounis A, Panabières F, Cahill D, Ruocco M, Figueiredo A, Chen XR, Hulvey J, Stam R, Lamour K, Gijzen M, Tyler BM, Grünwald NJ, Mukhtar MS, Tomé DFA, Tör M, Van Den Ackerveken G, McDowell J, Daayf F, Fry WE, Lindqvist-Kreuze H, Meijer HJG, Petre B, Ristaino J, Yoshida K, Birch PRJ, Govers F (2015) The top 10 oomycete pathogens in molecular plant pathology. Mol Plant Pathol. https://doi.org/10. $1111 / \mathrm{mpp} .12190$

13. Ploetz RC (2013) Phytophthora root rot of Avocado. In: Lamour K (ed) Phytophthora: a global perspective. CAB International, Wallingford, pp 197-203

14. Zentmyer GA (1980) Phytophthora Cinnamomi and the diseases it causes. Monograph American Phytopathological Society University of California, Riverside

15. O'Gara E, Howard K, McComb J, Colquhoun IJ, Hardy GESJ (2015) Penetration of suberized periderm of a woody host by Phytophthora cinnamomi. Plant Pathol. https://doi.org/10.1111/ppa. 12244

16. Jung T, Colquhoun IJ, Hardy GESJ (2013) New insights into the survival strategy of the invasive soilborne pathogen Phytophthora cinnamomi in different natural ecosystems in Western Australia. Forest Pathol. https://doi.org/10.1111/efp.12025

17. Choupina A, Cravador A, Carvalho M, Vaz M, Belo H, Martins F, Martins I (2014) Cloning, characterization and in vitro and in planta expression of a glucanase inhibitor protein (GIP) of Phytophthora cinnamomi. Mol Biol Rep. https://doi.org/10.1007/ s11033-014-3101-1

18. Choupina A, Branco J (2020) In silico characterization of the phytopathogenic efector, avr3a, from Phytophthora cinnamomi. J Basic Appl Sci. https://doi.org/10.29169/1927-5129.2020.16.03

19. Reitmann A, Berger DK, van den Berg N (2017) Putative pathogenicity genes of Phytophthora cinnamomi identified via RNA-Seq analysis of pre-infection structures. Eur J Plant Pathol 147:211-228. https://doi.org/10.1007/s10658-016-0993-8

20. Perrine-Walker F (2020) Use of cellophane to study the infection structures of PNG cocoa isolates of Phytophthora palmivora in vitro. Australas Plant Pathol 49:701-705. https://doi.org/10. 1007/s13313-020-00750-4

21. de Andrade Lourenço D, Branco I, Choupina A (2020) Phytopathogenic oomycetes: a review focusing on Phytophthora cinnamomi and biotechnological approaches. Mol Biol Rep 47:9179-9188. https://doi.org/10.1007/s11033-020-05911-8

22. Cantarel BL, Korf I, Robb SMC, Parr G, Ross E, Moore B, Holt C, Alvarado AS, Yandell M (2008) MAKER: an easy-to-use annotation pipeline designed for emerging 751 model organism genomes. Genome Res 18:188-196

23. Ali SS, Shao J, Lary DJ, Kronmiller B, Shen D, Strem MD, Amoako-Attah I, Akrofi AY, Begoude BA, Ten Hoopen GM, Coulibaly K, Kebe BI, Melnick RL, Guiltinan MJ, Tyler BM, Meinhardt LW,
Bailey BA (2017) Phytophthora megakarya and P. palmivora, closely related causal agents of cacao black pod rot, underwent increases in genome sizes and gene numbers by different mechanisms. Genome Biol Evol 9(3):536-557. https://doi.org/10.1093/ gbe/evx021

24. Yang M, Duan S, Mei X, Huang H, Chen W, Liu Y, Guo C, Yang T, Wei W, Liu X, He X, Dong Y, Zhu S (2020) The Phytophthora cactorum genome provides insights into the adaptation to host defense compounds and fungicides. Sci Rep. 8(1):6534. https:// doi.org/10.1038/s41598-018-24939-2. Erratum in: Sci Rep. 2020 10(1):7676

25. Adams TM, Armitage AD, Sobczyk MK, Bates HJ, Tabima JF, Kronmiller BA, Tyler BM, Grünwald NJ, Dunwell JM, Nellist CF, Harrison RJ (2020) Genomic investigation of the strawberry pathogen Phytophthora fragariae indicates pathogenicity is associated with transcriptional variation in three key races. Front Microbiol 15(11):490. https://doi.org/10.3389/fmicb.2020.00490

26. Jiang RH, Govers F (2006) Nonneutral GC3 and retroelement codon mimicry in Phytophthora. J Mol Evol 63(4):458-472. https://doi.org/10.1007/s00239-005-0211-3

27. Götesson A, Marshall J, Hardham A (2002) Characterization and evolutionary analysis of a large polygalacturonase gene family in the Oomycete plant pathogen Phytophthora cinnamomi. Mol Plant Microbe Interact. https://doi.org/10.1094/MPMI.2002.15.9.907

28. Williams FE, Varanasi U, Trumbly RJ (1991) The CYC8 and TUP1 proteins involved in glucose repression in Saccharomyces Cerevisiae are associated in a protein complex. Mol Cell Biol. https://doi.org/10.1128/mcb.11.6.3307

29. Huet J, Cottrelle P, Cool M, Vignais ML, Thiel MC, Buhler JM, Sentenac A, Fromageot P (1985) A general upstream binding factor for genes of the yeast translational apparatus. EMBO J. https:// doi.org/10.1002/j.1460-2075.1985.tb04114.x

30. Bechard LH, Butuner BD, Peterson GJ, McRae W, Topcu Z, McEachern MJ (2000) Mutant telomeric repeats in yeast can disrupt the negative regulation of recombination-mediated telomere maintenance and create an alternative lengthening of telomereslike phenotype. Mol Cell Biol. https://doi.org/10.1128/MCB. 00423-08

31. Conrad MN, Wright JH, Wolf AJ, Zakian VA (1990) RAP1 protein interacts with yeast telomeres in vivo: overproduction alters telomere structure and decreases chromosome stability. Cell. https://doi.org/10.1016/0092-8674(90)90140-a

32. Ferreira MG, Miller KM, Cooper JP (2004) Indecent exposure: when telomeres become uncapped. Mol Cell. https://doi.org/10. 1016/s1097-2765(03)00531-8

33. Hug N, Lingner J (2006) Telomere length homeostasis. Chromosoma. https://doi.org/10.1007/s00412-006-0067-3

34. Palm W, de Lange T (2008) How shelterin protects mammalian telomeres. Annu Rev Genet. https://doi.org/10.1146/annurev. genet.41.110306.130350

35. Autexier C, Lue NF (2006) The structure and function of telomerase reverse transcriptase. Annu Rev Biochem 75:493-517. https:// doi.org/10.1146/annurev.biochem.75.103004.142412

36. Collins K (2006) The biogenesis and regulation of telomerase holoenzymes. Nat Rev Mol Cell Biol. https://doi.org/10.1038/ nrm1961

37. Buchman AR, Lue NF, Kornberg RD (1988) Connections between transcriptional activators, silencers, and telomeres as revealed by functional analysis of a yeast DNA-binding protein. Mol Cell Biol. https://doi.org/10.1128/MCB.8.12.5086

38. Shore D (1994) RAP1: a protean regulator in yeast. Trends Genet. https://doi.org/10.1016/0168-9525(94)90058-2

39. Shore D, Nasmyth K (1987) Purification and cloning of a DNA binding protein from yeast that binds to both silencer and activator elements. Cell. https://doi.org/10.1016/0092-8674(87)90095-x 
40. Salowe SP, Marsh EN, Townsend CA (1990) Purification and characterization of clavaminate synthase from Streptomyces clavuligerus: an unusual oxidative enzyme in natural product biosynthesis. Biochemistry. https://doi.org/10.1021/bi00479a023

41. Evans J, Hannoodee M, Wittler M. Amoxicillin Clavulanate (2020) [Updated 2020 Apr 20]. In: StatPearls. StatPearls Publishing, Treasure Island. https://www.ncbi.nlm.nih.gov/books/NBK53 8164/. Accessed Jan 2020

42. Blackburn NT, Clarke AJ (2000) Identification of four families of peptidoglycan lytic transglycosylases. J Mol Evol. https://doi.org/ 10.1007/s002390010136

43. Fang W, Sanz AB, Bartual SG, Wang B, Ferenbach AT, Farkaš V, Guerrero RH, Arroyo J, Van Aalten DMF (2019) Mechanisms of redundancy and specificity of the Aspergillus fumigatus Crh transglycosylases. Nat Commun. https://doi.org/10.1038/ s41467-019-09674-0

44. Bi K, Jaiswal GN, Frid R, Zhu W, Masrati G, Mengiste T, Sharon A (2020) The Botrytis cinerea Crh transglycosylae is a cytoplasmic effector triggering plant cell death and defense response, "preprints." Cold Spring Harb Lab. https://doi.org/10.1101/2020. 06.23.166843

45. Battaglia E, Benoit I, van den Brink J, Wiebenga A, Coutinho PM, Henrissat B, de Vries RP (2011) Carbohydrate-active enzymes from the zygomycete fungus Rhizopus oryzae: a highly specialized approach to carbohydrate degradation depicted at genome level. BMC Genom. https://doi.org/10.1186/1471-2164-12-38

46. Coutinho PM, Andersen MR, Kolenova K, vanKuyk PA, Benoit I, Gruben BS, Trejo-Aguilar B, Visser H, van Solingen P, Pakula T, Seiboth B, Battaglia E, Aguilar-Osorio G, de Jong JF, Ohm RA, Aguilar M, Henrissat B, Nielsen J, Stalbrand H, de Vries RP (2009) Post-genomic insights into the plant polysaccharide degradation potential of Aspergillus nidulans and comparison to Aspergillus niger and Aspergillus oryzae. Fungal Genet Biol. https://doi.org/10.1016/j.fgb.2008.07.020

47. Martens-Uzunova ES, Schaap PJ (2009) Assessment of the pectin degrading enzyme network of Aspergillus niger by functional genomics. Fungal Genet Biol. https://doi.org/10.1016/j.fgb.2008. 07.021

48. Lulloff SJ, Hahn BL, Sohnle PG (2004) Fungal susceptibility to zinc deprivation. J Lab Clin Med. https://doi.org/10.1016/j.lab. 2004.07.007

49. Martins IM, Matos M, Costa R, Silva F, Pascoal A, Estevinho LM, Choupina A (2014) Transglutaminases: recent achievements and new sources. Appl Microbiol Biotechnol. https://doi.org/10.1007/ s00253-014-5894-1

50. Lewis ZA (2017) Polycomb group systems in fungi: new models for understanding polycomb repressive complex 2 . Trends Genet. https://doi.org/10.1016/j.tig.2017.01.006

51. Kielkopf CL, Lucke S, Green MR (2004) U2AF homology motifs: protein recognition in the RRM world. Genes Dev. https://doi.org/ $10.1101 / \mathrm{gad} .1206204$

52. Zhao ZS, Manser E (2012) PAK family kinases physiological roles and regulation. Cell Logist. https://doi.org/10.4161/cl.21912

53. Crighton D, Wilkinson S, O'Prey J, Syed N, Smith P, Harrison PR, Gasco M, Garrone O, Crook T, Ryan KM (2006) DRAM, a p53-induced modulator of autophagy, is critical for apoptosis. Cell. https://doi.org/10.1016/j.cell.2006.05.034

54. Yu EY, Yen WF, Steinberg-Neifach O, Lue NF (2009) Rap1 in Candida albicans: an unusual structural organization and a critical function in suppressing telomere recombination. Mol Cell Biol. https://doi.org/10.1128/MCB.00986-09

55. Den Brink JV, De Vries RP (2011) Fungal enzyme sets for plant polysaccharide degr adation. Appl Microbiol Biotechnol. https:// doi.org/10.1007/s00253-011-3473-2

56. Staats CC, Kmetzsch L, Schrank A, Vainstein MH (2013) Fungal zinc metabolism and its connections to virulence. Front Cell Infect Microbiol. https://doi.org/10.3389/fcimb.2013.00065

Publisher's Note Springer Nature remains neutral with regard to jurisdictional claims in published maps and institutional affiliations. 